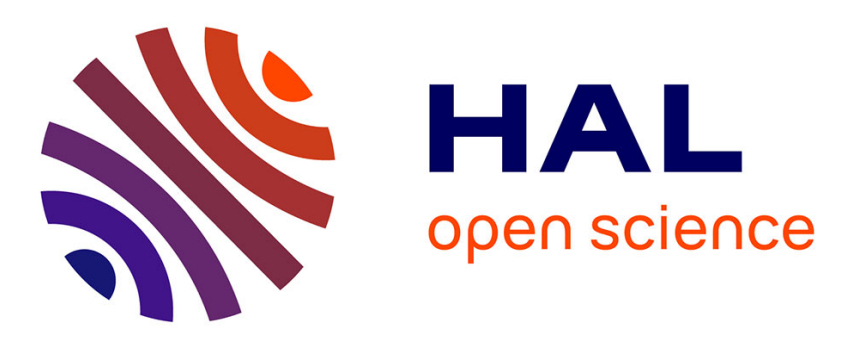

\title{
Testing oceanic subduction and convective removal models for the Gibraltar arc: Seismological constraints from dispersion and anisotropy
}

Götz Bokelmann, Emeline Maufroy, Luisa Buontempo, José Morales, Guilhem Barruol

\section{To cite this version:}

Götz Bokelmann, Emeline Maufroy, Luisa Buontempo, José Morales, Guilhem Barruol. Testing oceanic subduction and convective removal models for the Gibraltar arc: Seismological constraints from dispersion and anisotropy. Tectonophysics, 2011, 502, pp.28 - 37. 10.1016/j.tecto.2010.08.004 . hal-01388041

\section{HAL Id: hal-01388041 \\ https://hal.univ-reunion.fr/hal-01388041}

Submitted on 26 Oct 2016

HAL is a multi-disciplinary open access archive for the deposit and dissemination of scientific research documents, whether they are published or not. The documents may come from teaching and research institutions in France or abroad, or from public or private research centers.
L'archive ouverte pluridisciplinaire HAL, est destinée au dépôt et à la diffusion de documents scientifiques de niveau recherche, publiés ou non, émanant des établissements d'enseignement et de recherche français ou étrangers, des laboratoires publics ou privés. 


\title{
Testing oceanic subduction and convective removal models for the Gibraltar arc: Seismological constraints from dispersion and anisotropy
}

\author{
Götz Bokelmann ${ }^{\mathrm{a}, *}$, Emeline Maufroy ${ }^{\mathrm{b}}$, Luisa Buontempo ${ }^{\mathrm{c}}$, José Morales ${ }^{\mathrm{c}}$, Guilhem Barruol ${ }^{\mathrm{a}}$ \\ a Université Montpellier II, CNRS, Geosciences Montpellier, 34095 Montpellier, France

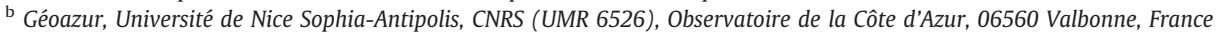 \\ ${ }^{\mathrm{c}}$ Instituto Andaluz de Geofisica, Universidad de Granada, Spain
}

\begin{abstract}
A B S T R A C T
We discuss mantle structure and dynamics under the Gibraltar arc. For that region, a large variety of geodynamic models has been proposed, and there was, up to recently, no consensus on which of these models is the best one to describe the geodynamic situation of the region. The key to distinguishing the different models probably lies in the upper mantle, and we propose two specially adapted seismological techniques that help to distinguish each of the two models that are more frequently invoked. These are, on one hand, the subduction-rollback (SR) model, and on the other, continental delamination or convective removal (CDCR). The first technique that we use is based on observations of dispersed P-wavetrains that are expected for certain ray directions. Observations made on the Gibraltar arc suggest the presence of subducted oceanic lithosphere under the Alboran Sea. The second technique is based on shear-wave splitting of SKS phases, and it allows us to look for the radially-oriented flow that must be present in the mantle beneath the Alboran Sea, for a CDCR mechanism. There are however no indications of any radial flow up to this point. Both approaches therefore suggest that subduction-rollback is the best model to explain the complex geodynamic situation under the region.
\end{abstract}

\section{Introduction}

Oceanic lithosphere is recycled into the deep interior of the Earth at subduction zones. While the general principles of this conveyorbelt like motion are understood, this question is more open for continental lithosphere. It is clear though that continental subduction exists, for example from high-pressure phases (e.g. Coleman and Wang, 1995; Yamato et al., 2008).

Several models have been proposed to explain how, in which cases, and where continental recycling takes place. Bird (1979) has proposed that this occurs via lithospheric delamination, while Houseman et al. (1981) have proposed convective removal of a dense overthickened lithospheric root. These two types of models have been invoked to explain various extensional basins around the Earth, and particularly extensional basins along the Alpine convergence zone between Europe and Africa, such as the Pannonian basin and the Alboran Sea basin (Fig. 1).

In this paper, we focus on the latter region, the Alboran Sea between Spain and Morocco, also addressed as 'Gibraltar arc region'. That region has been much studied, and a wealth of information is available about its surface tectonics (e.g. Dallmeyer and Martínez

\footnotetext{
* Corresponding author. Fax: +33467143603.

E-mail address: bokelmann@gm.univ-montp2.fr (G. Bokelmann).
}

García, 1990; García-Dueñas et al., 1992; Jabaloy et al., 1992; Crespo-Blanc et al., 1994; Martínez-Martínez and Azañón, 1997; Michard et al., 2002; Martínez-Martínez et al., 2006; Balanyá et al., 2007; Jolivet et al., 2008, and others), current motion (e.g. Stich et al., 2006), magmatism (e.g. Turner et al., 1999), and crustal magnetics (see Michard et al., 2002). In addition, there is considerable information from seismicity in the region, focal mechanisms (Stich et al., 2003), as well as petrogeochemical data from magmatic rocks (Duggen et al., 2004, 2005), large-scale mantle outcrops (e.g., Vauchez and Garrido, 2001) and xenoliths (Turner et al., 1999).

Nevertheless, this wealth of information has apparently not lead to a consensus on the type of model that best explains the geodynamic situation and evolution in the region. In the contrary, there is an ongoing debate as to that effect (Gutscher et al., 2002, 2003; Platt and Houseman, 2003). For resolving structure and dynamics of a region, much hope is generally attributed to seismic tomography, and that type of constraint has been extensively used in recent years (e.g., Blanco and Spakman, 1993; Calvert et al., 2000a; Wortel and Spakman, 2000). However, ray coverage in the area is not favourable, and as explained in more detail below, resolution is thus limited. In addition, seismic tomography cannot distinguish easily between oceanic and continental lithosphere, since both appear in tomographic images with similar velocity. In fact, average velocities of the two types of lithosphere are nearly identical. 


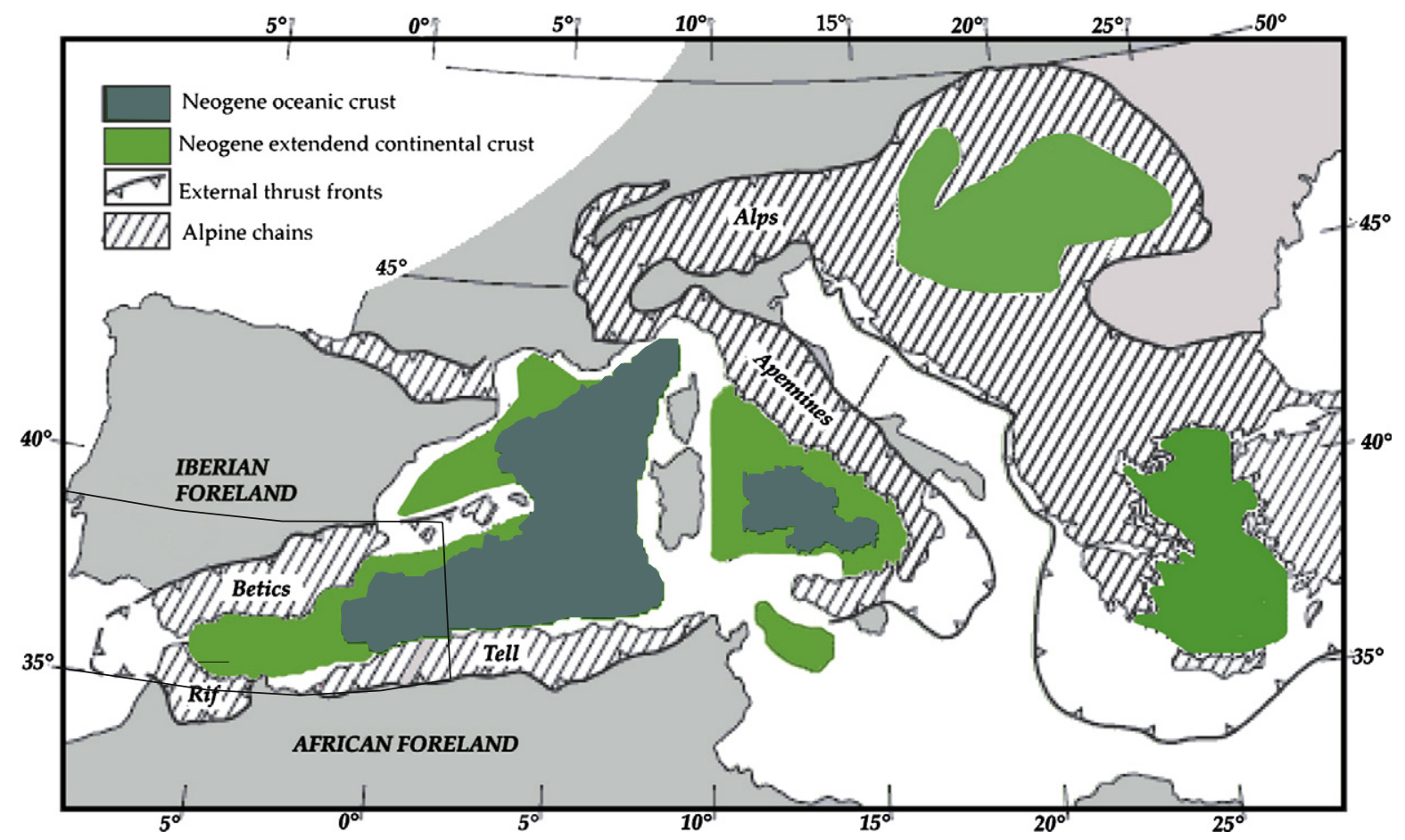

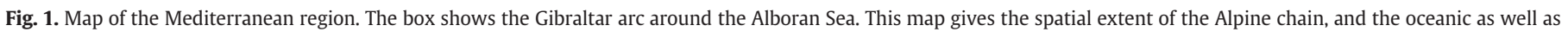
extended continental crust (after Comas et al., 1999).

Our approach is instead based on directly testing the geodynamic models, using adapted seismological techniques. We extract essential and required features from each model such as associated structure and mantle flow, and we present two techniques that allow to critically test each of the two models, and to distinguish them. The key to understanding the geodynamic situation of the region probably lies in the upper mantle, and we thus focus our attention on that depth region, and on the seismic waves that propagate through it. We use constraints based on observations of P-wave dispersion that are indicative of anomalous (layered) structure along the propagation path, and also seismic anisotropy, since it is capable of constraining the geometry of mantle flow, which is also rather indicative of the kind of geodynamic environment.

\section{Test case of lithospheric recycling: the Alboran Sea region}

The geodynamic situation of the Alboran Sea region is typically approached by considering one of the two large-scale tectonic processes that occurred in the Mediterranean area, that is, a) the Cenozoic opening of the western Mediterranean, thus addressing the role of the extension and formation of oceanic lithosphere, and b) the collision of Europe and Africa, thus addressing the role of the continental lithosphere during the collision. The many geodynamic models that have been proposed for the region thus typically fall into one of two categories, either 'oceanic models' or 'continental models'. The ocean models suggest subduction of oceanic lithosphere that is either ongoing or has ceased its activity. Different dip directions of the subduction are considered in these models (Torres-Roldan et al., 1986; Sanz de Galdeano, 1990; Royden, 1993; Docherty and Banda, 1995; Lonergan and White, 1997; Morales et al., 1999; Gutscher et al., 2002), but most models assume an eastward-dipping subduction. On the other hand, 'continental models' propose past or present subduction, delamination, or convective removal of overthickened continental lithosphere (Platt and Vissers, 1989; Seber et al., 1996a; Morales et al., 1999; Calvert et al., 2000a). These two types of models are illustrated in Fig. 2.
Geological indications of a westward migration of the orogenic arc suggested the presence of an 'Alboran block' (Andrieux et al., 1971) that escaped to the West during the North-South convergence. An

\section{a) Oceanic model (retreating subduction)}

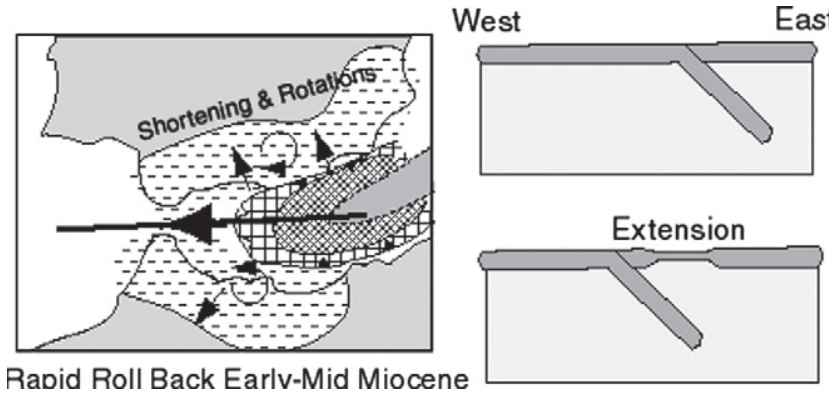

b) Continental model (convective removal)
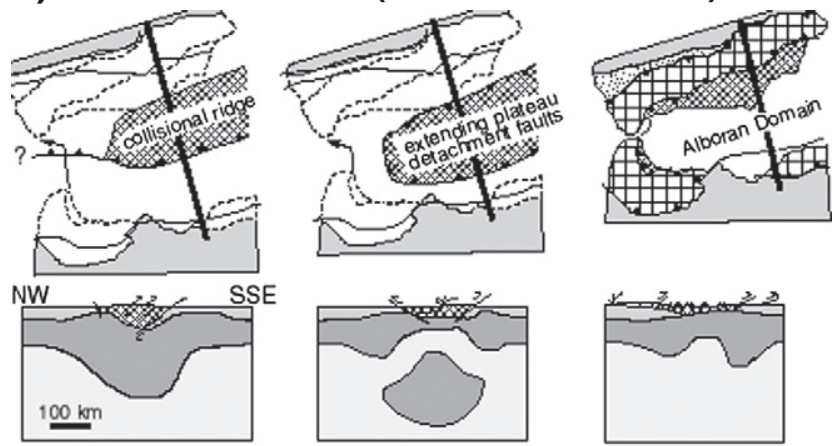

Oliqocene

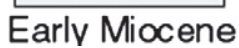

Present

Fig. 2. (Redrawn from Calvert et al., 2000a): The two types of geodynamic models that we test in this paper, a) the retreating subduction model of Lonergan and White (1997) and Gutscher et al. (2002), and b) the convective removal model of Platt and Vissers (1989). For explanations see the text. 
a)

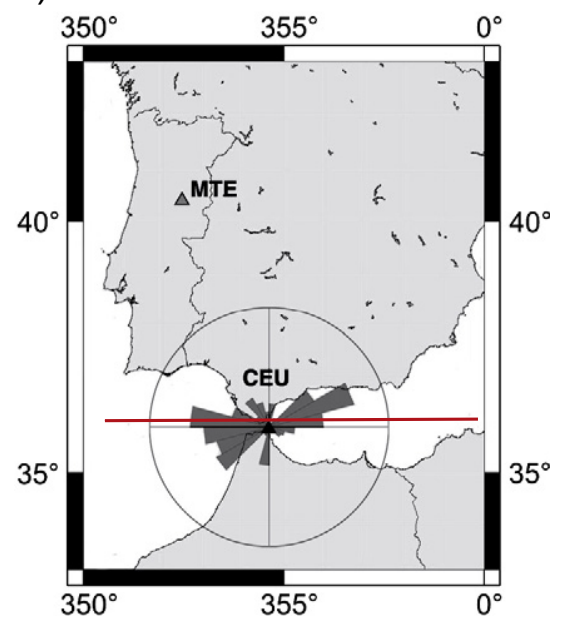

b)

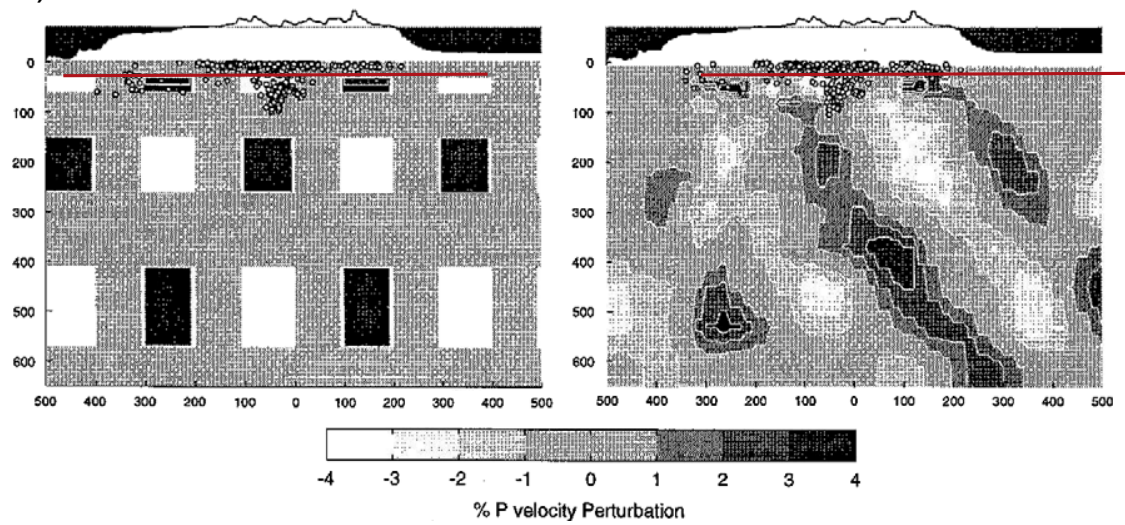

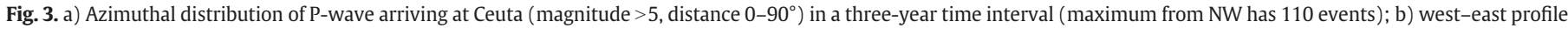
(see a) through 3D input model for tomographic resolution test, and resulting output model (after Calvert et al., 2000a). See text for explanations.

eastward-dipping subduction zone rolling back toward the West (Fig. 2a) would naturally explain this, and also the extension that has subsequently been identified, and incorporated into the model (Royden, 1993). The latter author suggested that arc migration has actually continued beyond Gibraltar, while other authors have suggested that the motion has stopped retreating in the Gibraltar area (Sengör, 1993; Lonergan and White, 1997). Yet other models suggest that a Northwest dipping slab has subducted beneath Iberia, and has later broken off, producing uplift and extension. It would still be positioned steeply under Andalusia (Blanco and Spakman, 1993; Zeck, 1996).

The alternative set of models explains the anomalous mantle under the Alboran Sea by considering recycling of continental lithosphere by delamination or by convective removal. Fig. $2 \mathrm{~b}$ illustrates the latter. Platt and Vissers (1989) have suggested, based on PT-paths of rocks across the Gibraltar arc that convergence has lead to considerable lithospheric thickness, and that the lithosphere became gravitationally unstable and was removed and replaced by low-density asthenospheric material, resulting in uplift and extension. Platt et al. (1998) proposed that removal of the lithosphere occurred at a (shallow) depth of about $60 \mathrm{~km}$. Another way to remove continental lithosphere is by delamination (Bird, 1979). A model of SE migrating delamination has been applied to the Alboran Sea region by Docherty and Banda (1995) and is coherent with the distribution of seismicity hypocenters (Mezcua and Rueda, 1997; Morales et al., 1999), and with the variation of seismic velocities found in the mantle below the Alboran Sea (Seber et al., 1996b). It also has been suggested that Iberian and African lithosphere has peeled back from the East to the West (Seber et al., 1996a), this process being initiated by a gravitationally unstable lithospheric root under the Internal zone of the Gibraltar arc.

Proponents of the two types of models, 'oceanic models' versus 'continental models', have lead a debate over the last decade. Arguments for and against each of the two models have been layed out clearly in a comment and reply series (Gutscher et al., 2002, 2003; Platt and Houseman, 2003). The authors had suggested that discriminating tests should be proposed. In the following we present techniques that allow to critically test each of the two models using seismic waves that propagate through the zone. The upper mantle under the Alboran Sea is indeed clearly anomalous. This is most easily seen by inspective the variation of teleseismic station delay times across the region (e.g., Calvert et al., 2000a). Tomographic studies have proposed the presence of a high-velocity anomaly (see below).

We propose that distinguishing the two types of models requires resolving two questions, 1) what is the nature of that high-velocity anomaly, e.g., is it composed of oceanic or of continental lithospheric material?, and 2) what is the shape of the anomaly? We will suggest below that up to recently, neither of these two questions has been well-resolved. We will thus focus on these two questions, and propose techniques that are designed to directly address them. Before that, we address seismic tomography in the area.

Tomography studies have been performed for the area ever since the early 90s (Blanco and Spakman, 1993; Plomerova et al., 1993; Spakman et al., 1993; Seber et al., 1996b; Piromallo and Morelli, 1997; Bijwaard et al., 1998; Calvert et al., 2000a). All of these studies document the presence of a high-velocity anomaly under the Alboran 
Sea. Most of them used ISC travel times, but Seber et al. (1996b), Gurria et al. (1997), and Calvert et al. (2000a) also included data from the Moroccan national and/or Spanish network. There are also studies of crustal structure in the area (e.g., Calvert et al., 2000b; Villasenor et al., 2007; Serrano et al., 2005; and others).

The resolution of tomographic models depends greatly on the seismic ray coverage at depth. Fig. 3a shows a rose diagram indicating the number of P-waves arriving at one of the seismological stations in the area (Ceuta). Note that there are many arrivals from East and West, but only few from North and South. Ray backazimuthal coverage is clearly not complete. This is accentuated by the sea/land distribution in the area that has necessarily led to a gap in instrumental coverage. Only recently, OBS have been installed in the Alboran Sea and the Gulf of Cadiz to alleviate that lack of coverage.

The incomplete ray coverage in the area indicates that it is necessary to inspect resolution capability of tomographic models obtained for the area. Given the asymmetry of ray density, it will probably be easier to define the EW extent of structures in the subsurface than their NS extent. Calvert et al. (2000a) have taken much care with extracting arrival times from 96 regional stations in Morocco and Spain. Thus they were able to update the ISC arrival time dataset by about 200 regional and teleseismic events. The tomographic inversion was based on a nonlinear maximum likelihood formalism. First, the best-fitting 1D model was constructed that served as initial model for the 3D inversion. Resolution in resulting 3D models can be judged by inspecting the hit count, standard errors from the a-posteriori covariance matrix or from bootstrap resampling, the resolution matrix elements, and all of these tests were performed by Calvert et al. (2000a). The most commonly used test is the 'spike test', where synthetic data are generated by ray tracing through a given velocity model that consists of a regular pattern of high- and low-velocity anomalies. With some noise (random delays) added, these synthetic data are inverted, and the recovered model is compared with the input model.

Regions where the output model matches the input model are regarded as well-constrained, while regions that show substantial difference between the two models are regarded as badly-constrained. There are issues as to the geometry of the synthetic test, and as to the choice of the block size. In particular, a spike test does not give any information on the range of other models that cannot be recovered by the inversion, but these issues are beyond the scope of the present paper.

Fig. 3b shows an East-West profile through the spike test input model, at the latitude of Gibraltar. Ray tracing through that model produced synthetic travel times, to which representative random delays were added. In addition, the block parameterization of the inversion was shifted relative to the input model. Fig. $3 \mathrm{~b}$ also shows the output model. Comparison with the input model indicates that most of the anomalous blocks show up after the inversion. Resolution is typically better in the deeper layers than the shallower ones, due to the higher number of crossing ray paths. Thus blocks at shallow depth and at the edge of the station coverage are less-well imaged. Such a comparison would typically be judged as a success, since most blocks were recovered. However, as to the interpretation of the shape of the anomaly, there is a caveat. There is significant smearing toward the East, apparently along the paths of the majority of the rays. Such smearing produces tomographic images that resemble an elongated dipping feature, even though the true shape of the feature is perhaps just like that chosen in the input model. Even though individual blocks are well-resolved, the interpretation in terms of geodynamic models is obviously much lesswell constrained. In a way, we are more interested in the validity of the interpretation rather than that of the tomographic model, on which the interpretation is based on. Neither of the above mentioned tests so far has addressed the validity of the interpretation. Clearly, we need more technical development in that direction to assure that we make the best use out of the very valuable information that tomography offers.
As far as our specific objectives are concerned, namely determining the nature of the anomaly, tomography has yet another limitation though: oceanic and continental lithosphere are associated with rather similar velocity anomalies, unless very high resolution can be achieved, and they can hardly be distinguished on that basis. The strength of tomographic constraints for understanding the nature of the anomaly will for that reason always remain limited. Its strength is rather in addressing the second question posed above, that of the shape of the anomaly.

\section{Testing the oceanic model: dispersion of body waves}

We will now return to the geodynamic models of Fig. 2, and address tests that can be set up to determine the nature of the anomaly, e.g., whether the anomaly consists of oceanic or of continental lithosphere. The 'retreating subduction' model of Fig. 2a suggests the presence of a 'slab', that is, subducted oceanic lithosphere, under the Alboran Sea.

The typical East-West ray distribution that we have seen in Fig. 3a, which poses a problem for tomography, has the advantage that some rays may propagate more or less parallel to the anomalous feature in the upper mantle. If that feature does indeed represent subducted oceanic lithosphere, it is somewhat likely that it still contains the oceanic crust/mantle series and that it forms thus an inclined layer cake. Waveforms of seismic waves that propagate parallel to such a structure (Fig. 4a) can easily be modelled using seismological modelling tools (e.g. Gubbins and Snieder, 1991; Abers, 2005; Martin, 2005). In fact, waveforms of body waves propagating along the slab may attain similar properties than surface waves, namely a frequencydependent propagation velocity (dispersion) that is due to different frequencies being sensitive differently to the layer. Higher frequency components can propagate within the low-velocity crustal portion of the layer cake, while lower frequencies are more sensitive to average

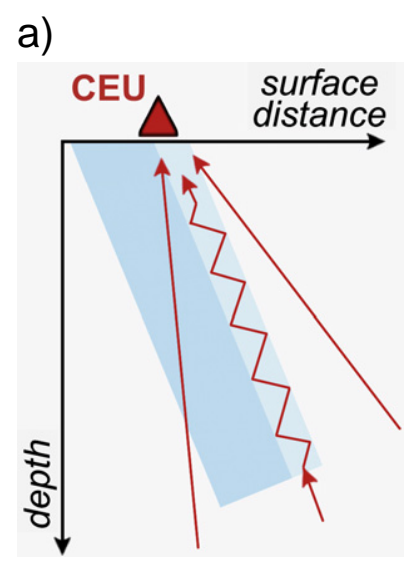

b)

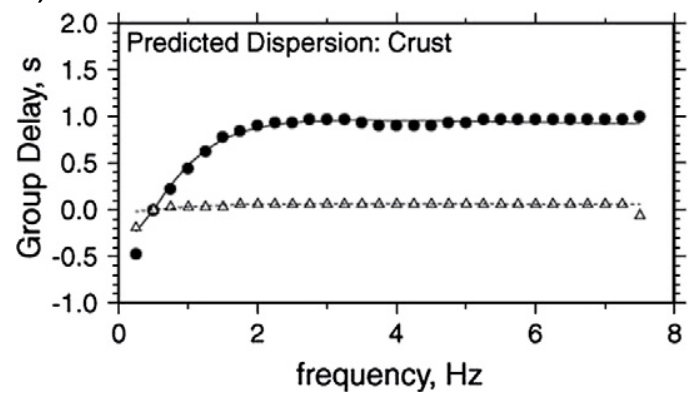

Fig. 4. a) Illustration of ray propagation parallel to subducted oceanic lithosphere, b) group arrival times as a function of frequency (dispersion) for a $6 \mathrm{~km}$ thick crustal low-velocity channel $(8 \mathrm{~km} / \mathrm{s})$ embedded in a background velocity of $8.5 \mathrm{~km} / \mathrm{s}$ (redrawn after Abers, 2005). 
a)

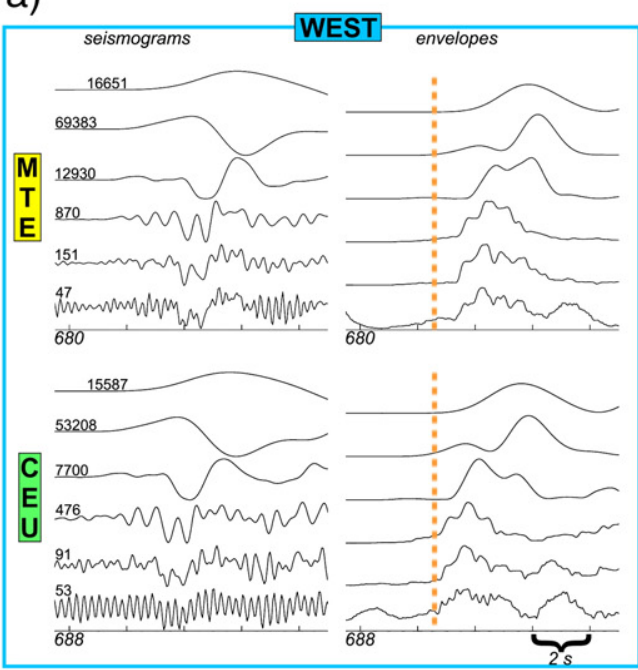

b)



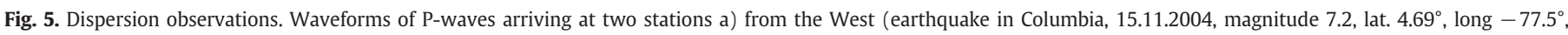

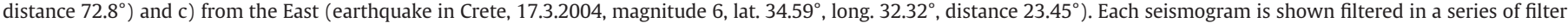

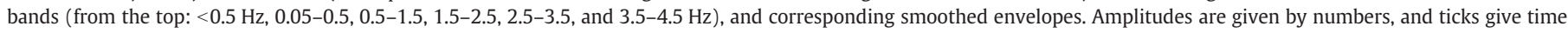
intervals of $2 \mathrm{~s}$. The observed dispersion is illustrated by a dashed line. See text for explanation.

velocities. This should produce a 'normal' dispersion, where high frequencies around $5 \mathrm{~Hz}$ are delayed by about a second with respect to lower frequencies around $0.5 \mathrm{~Hz}$ (Fig. 4b). Such a dispersion has been observed in several subduction zones around the Pacific (Abers and Sarker, 1996; Abers, 2005) and in the following, we show evidence indicating that such a phenomenon is also present for waves that propagate below the Gibraltar arc.

Fig. 5 shows waveforms from two teleseismic events observed at two stations, MTE in Portugal and CEU in Ceuta. The latter station has a fortunate location, in that it is positioned along the continuation of the high-velocity anomaly in tomographic models (see for example Gutscher et al., 2002). That station is thus at the ideal location for looking for the described dispersion phenomena. On the other hand, the station in Portugal serves as a reference station, so that we can assure that any observed dispersion is really due to the anomalous upper mantle under the Alboran Sea, and not due to effects at larger distance or due to the earthquake source.

Fig. 5c shows P-waves arriving from the East, for an earthquake occurring in Crete. The seismograms were filtered in a series of frequency bands. Waveforms are complicated, and smoothed envelopes are useful for tracing the arrival time across the different frequencies. The envelopes show an interesting difference between the two stations. While all frequencies arrive at about the same time at the reference station MTE, there is a clear dispersion at station CEU. High frequencies arrive up to about one second after the lowfrequency arrivals. This effect is similar to that seen in numerical modelling (Fig. 4b), and also to the observations from known subduction zones around the Pacific (Abers and Sarker, 1996; Abers, 2005). The P-waves arriving from the West, in Fig. 5a, do not show such a difference between the two stations. In fact, there is hardly any frequency dependence of arrival times at the two stations, somewhat similar to the arrival from the east at MTE. The anomalous behaviour that requires explanation is the Eastern arrival at CEU that is passing through the upper mantle under the Alboran Sea.

We have studied a larger number of events for their dispersion behaviour. Fig. 6 shows lower hemisphere positions of rays that show dispersion, versus those that don't. In a number of cases we have assigned an 'unclear', when the signal-to-noise ratio was too low to characterize the dispersion either due to an unclear first arrival, or if there was an unclear frequency trend. Note the clear asymmetry in the lower hemisphere under CEU. Many arrivals from the East show dispersion, while most arrivals from the West show clear absence of dispersion. At the reference station MTE, essentially all arrivals show either absence of dispersion or unclear behaviour. There are only two that show dispersion. These events occurred in the Alboran Sea themselves. The different patterns at the two stations, as well as the
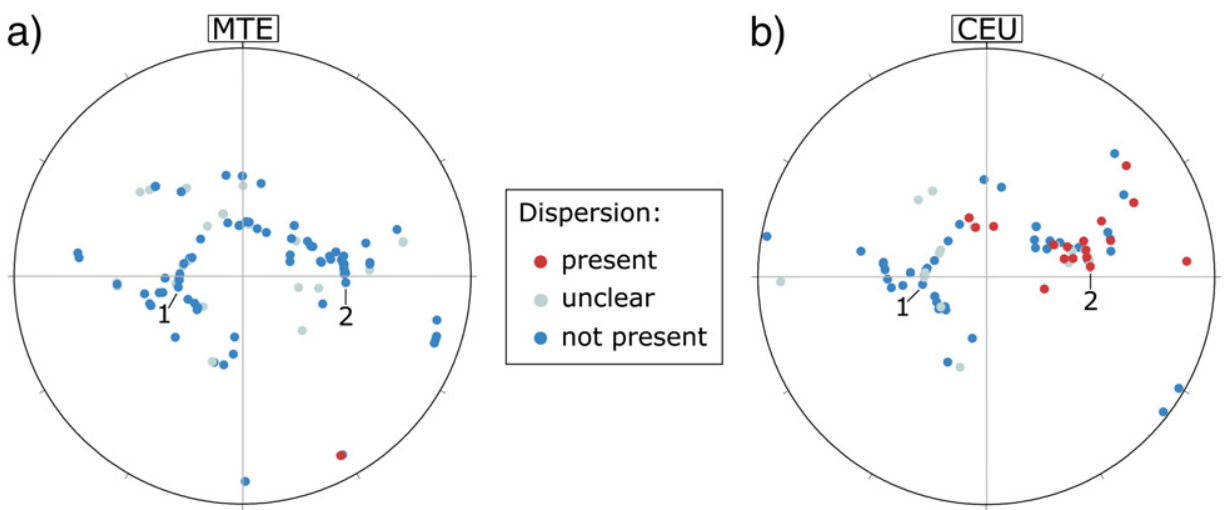

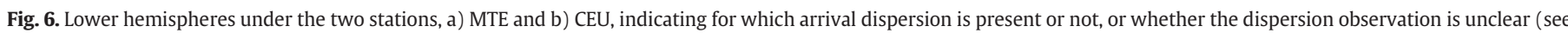
text). The events of Fig. 5 are shown by " 1 " and "2". 


\section{BEFORE}

a)



b)

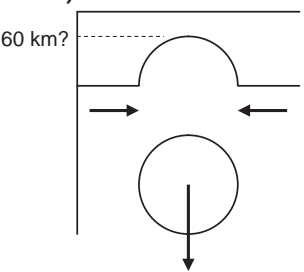

AFTER

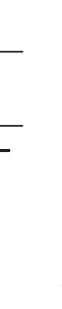

CHANNEL FLOW MODEL

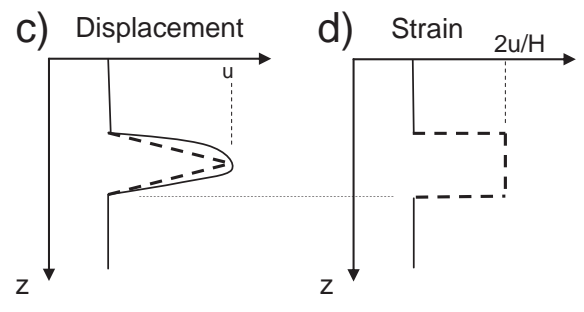


displacement and strain during a channel flow. Dashed lines show the case of a constant strain-rate flow. The height of the channel is H; D is its lateral extent.

East-West asymmetry at CEU are coherent with the presence of one or more oceanic slabs under the Alboran Sea.

We have studied alternative explanations such as attenuation, scattering, or multiple phases, and we have not found any simple process that explains these observations other than dispersion due to layering in an oceanic lithosphere (see also Bokelmann and Maufroy, 2007). We will come back to this in more detail below.

\section{Testing the continental model: anisotropy}

The continental model presented in Fig. $2 \mathrm{~b}$ proposes that a gravitationally unstable continental root has separated from the upper portion of the lithosphere and has foundered into the deeper mantle. The lithospheric root is thus replaced by asthenospheric material, which must be brought in from the side. In idealized theoretical models (Houseman and Molnar, 1997), this flow occurs simultaneously from all directions. Obviously, any lateral difference in 'boundary conditions' in the real Earth, as well as heterogeneity in temperature and material properties will perturb this symmetry however. In a real Earth, such a radial replacement flow would probably occur preferentially from one side, especially if the foundering of continental material occurs in the form of "continental delamination'. In any case, the occurrence of radial flow represents a necessary feature for any continental-type model (also for continental delamination), and we can use it to critically test the continental model.

The induced flow in the upper mantle to replace the material of a foundering overthickened continental lithosphere (Fig. 7a,b) will to some degree resemble a channel flow (Fig. 7c), since it must necessarily come in from the side. We do not know from which side that flow comes in, but it must necessarily be present at least one of the edges of the model. The summary Fig. 9 thus shows a prediction of radial flow. In a channel flow model, we are dealing with simple shear deformation with a horizontal flow direction. Seismic fast azimuths should thus match the (horizontal projection of) flow direction somewhere around the Alboran Sea. This will allow us to directly compare those predicted directions of radial flow with observed fast orientations (see below).

Flow directions in the mantle can be mapped by anisotropy measurements, e.g. directional dependence of material properties. We will study in the following elastic anisotropy, as seen by seismic waves. Such seismic anisotropy has been much studied over the last twenty years, and it is now well-established as a technique. Seismic anisotropy in the upper mantle results primarily from elastic anisotropy of minerals, particularly olivine, which develop preferred orientations in response to flow and stress (e.g., Nicolas and Christensen, 1987; Mainprice et al., 2000). Upper mantle seismic anisotropy can be detected from the splitting of teleseismic shear waves: a polarized shear-wave propagating through an anisotropic medium is split into two perpendicularly polarized waves (Fig. 8) that travel at different velocities. From three-component seismic records, two parameters can be measured to quantify anisotropy: the difference in arrival time $(\delta t)$ between the two split waves, which depends on the thickness and on the degree of intrinsic anisotropy of the medium, and the azimuth $\Phi$ of the fast split shear-wave polarization plane that is related to the orientation of the pervasive fabric (foliation and lineation) in the anisotropic structure. Measurement of teleseismic shear-wave splitting is therefore used to probe mantle deformation beneath a station, with a relatively good lateral resolution (tens of kilometers) that can provide crucial information on past and present geodynamic processes that occurred in the upper mantle. This technique has been applied to similar domains as here; see reviews in Savage (1999) and Silver (1996), and more specifically Walker et al. (2001, 2004a,b, 2005), Fontaine et al. (2007), and Barruol et al. (2008).

If one assumes that most of the anisotropy affecting the vertically propagating shear waves lies within the uppermost $400 \mathrm{~km}$ of the Earth (e.g., Savage, 1999; Mainprice et al., 2000, 2005; Sieminski et al., 2007) and that the crust may contribute to the total observed delay times by only a few tenths of seconds (Barruol and Mainprice, 1993; Godfrey et al., 2000), then most of the SKS splitting has to be explained by deformation in the upper mantle.

We have analyzed shear-wave splitting at a set of 16 stations around the Alboran Sea. Requiring a reasonable signal-to-noise ratio allowed us to use 267 seismograms from 67 teleseismic events. The SplitLab tool of Wüstefeld et al. (2008) was used to perform the splitting analysis, resulting in measures of fast orientations and splitting delay times. Details of data and results are given in Buontempo et al. (2008). These are coherent with results from earlier



Fig. 8. Principle of seismic shear-wave splitting due to anisotropy (see text). 


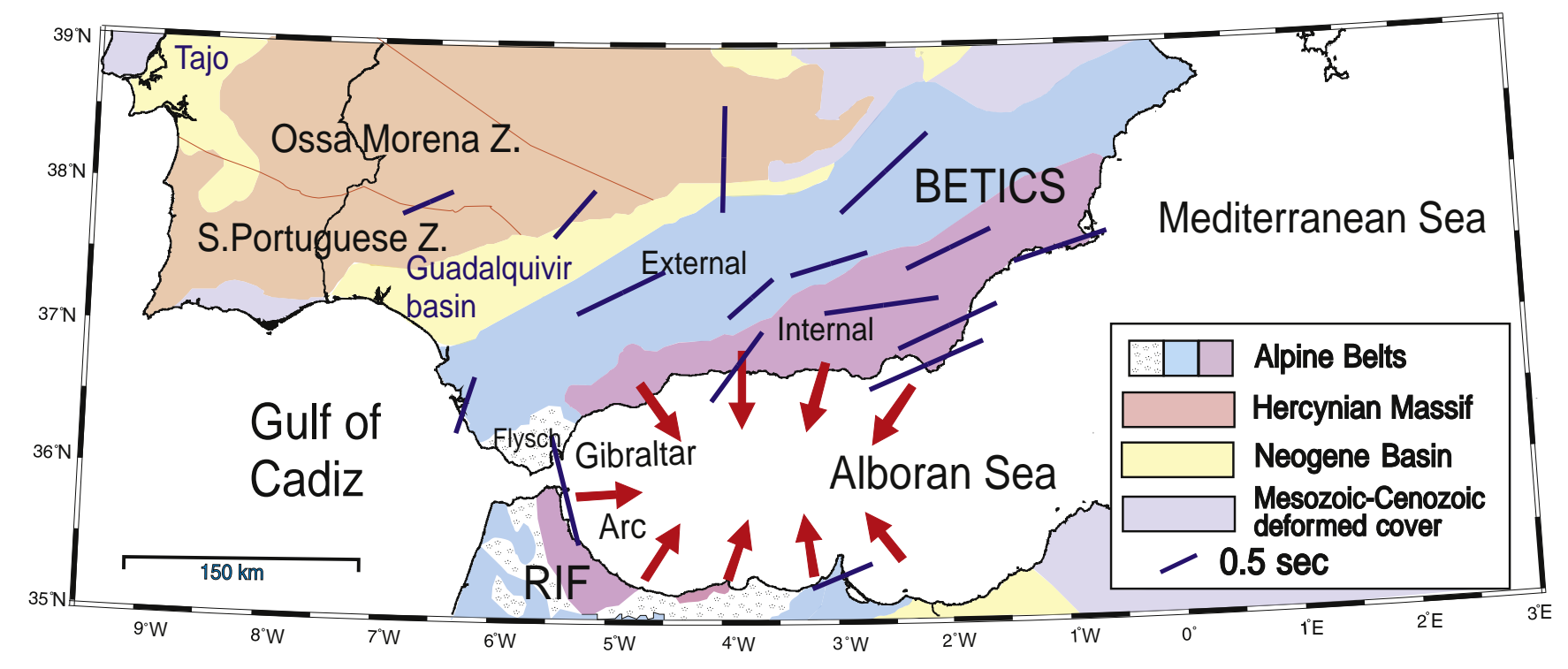

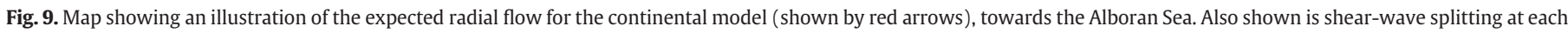
of the 16 stations: Weighted-mean fast orientations are given by the direction of the line. Splitting delays are given by its length.

studies (e.g., Diaz et al., 1998; Schmid et al., 2004). We show weighted-means for each station in Fig. 9. Since fast orientations should be identical with the horizontal flow direction, we can directly compare the predicted flow directions (arrows) and the observed fast orientations. We note that there is little indication, in the available splitting data, of such a radial flow toward the Alboran Sea. Essentially, all stations show fast orientations that are more or less tangential to the Alboran Sea, rather than radial. Particularly in the Betics, the fast split orientations are trending parallel to the crustal large-scale tectonic structures, suggesting some coherency between crustal and mantle deformation. A single station, ANER on the Spanish coast at latitude $4^{\circ} \mathrm{W}$, shows a slight rotation toward the arc. Shear-wave splitting measurements at that station showed a variation with event backazimuth, which is an indication of a possible two-layer structure (Silver and Savage, 1994). We have analyzed the backazimuthal dependence, and determined parameters of the two-layer model that best fits the observations (Buontempo et al., 2008). We have found fast orientations of $28^{\circ}$ in the shallower layer, and $68^{\circ}$ in the deeper layer, and delay times were 1 and $0.6 \mathrm{~s}$, respectively. We note that both of these directions are different from the predicted radial-flow direction in Fig. 9. This suggests that a convective removal model is not supported by the SKS splitting data that are available so far. At least on the northern side of the Alboran Sea, Pn waves show a rather similar spatial pattern of fast orientation as SKS (Calvert et al., 2000b; Buontempo et al., 2008) suggesting some coupling between the subcrustal and the deeper mantle.

We note a considerable gap in coverage in Northern Morocco (and in the Eastern Alboran Sea). Does the radial flow 'hide' in those regions? This does not seem likely, also in light of recent geodetic observations in the region of that gap (Fadil et al., 2006) that show surface motion in the opposite direction, toward the Southwest. In any case, that question can be addressed using data from the IberArray and PICASSO projects. First results (Diaz et al., 2009) from the IBERARRAY broadband seismic network seem to confirm our observations.

\section{Discussion}

One way of explaining why predictions from the continental model are not matched by the observations is perhaps that the effect of the flow on seismic anisotropy is too weak to be observable. We test this possibility in the following.
The required radial replacement flow can be modelled, in a rough approximation, as a channel flow (Fig. 7). For a constant-strain profile of flow, the volume of transported material is $\mathrm{DHu} / 2$. Equating this to the estimated volume of the root replacement $V_{r}$, which we estimate as $(150 \mathrm{~km})^{3}$, we obtain a maximum displacement of $300 \mathrm{~km}$, choosing for simplicity $\mathrm{H}=\mathrm{D}=150 \mathrm{~km}$. The strain in the channel is then $\varepsilon=2 \mathrm{u} /$ $\mathrm{H}=4$. The depth and temperature range considered here falling clearly into the dislocation creep regime (Karato and Wu, 1993), a strain of 4 should produce strong anisotropy (Mainprice and Silver, 1993; Silver et al., 1999) and detectable (one second or more) shear-wave splitting. Distributed over a $150 \mathrm{~km}$ thick channel, this flow should be observable even if the channel has a lateral extent comparable to the entire Southern limit, about $600 \mathrm{~km}$ length. The observed anisotropy that doesn't indicate any sign of this radial flow thus appears to clearly rule out radial flow, and hence a continental-type model.

While the anisotropy constraint is very strong for ruling out a purely continental model, it is weaker for ruling out or confirming a subduction model. In principle, we expect a trench-parallel flow during the rollback (Russo and Silver, 1994; Faccenna et al., 2004, 2005), and such a 'toroidal flow' (tangential) component is rather consistent with the 'trench-parallel' fast orientations that we observe here. On the other hand, fast orientations from known subduction zones around the Earth are typically either trench-parallel or trenchperpendicular (Long and Silver, 2008). Some of the complexity seen at the different subduction zones around the Earth may be due to a particular olivine fabric that forms under hydrated conditions (Jung and Karato, 2001), especially in the mantle wedge above the slab. Since teleseismic shear-wave splitting observations give only weak constraints on the depth of the anisotropy, we conclude that our splitting observations are consistent with the presence of a subduction zone, but they do not allow to critically test that model.

On the other hand, a subduction model makes a clear prediction as to the dispersion of body waves, and we have used that constraint to critically test the subduction zone model. We have found the predicted phenomenon for numerous waves propagating through the mantle under the Alboran Sea. In this study, we have in fact never found that behaviour for rays that do not pass through the anomalous zone beneath the Alboran Sea. It is rather difficult to explain these observations otherwise, without invoking a subduction model (see Bokelmann and Maufroy, 2007). On the other hand, one might wonder whether the dispersion might be produced by propagation within continental crust that is taken down into the mantle with a 
piece of continental lithosphere. This seems very unlikely however, since convective removal and delamination models typically propose to separate and founder only deeper portions of the lithosphere. If some crust were to descend nevertheless, it would have to remain nearly unperturbed though, to keep its planar and elongated shape. This seems extremely unlikely.

The observed dispersion thus gives an important constraint on the nature of the anomaly (oceanic rather than continental lithosphere). On the other hand, the constraint on shape is relatively weak, and does not go much beyond fixing the general location of the oceanic slab to be under the Alboran Sea.

Other pieces of evidence that point to subduction rather than removal of continental lithosphere as a zeroth-order model for the area are east-dipping reflectors in the Gulf of Cadiz (Gutscher et al., 2002; Thiebot and Gutscher, 2006) that suggest the presence of an eastward-dipping accretionary wedge. Block rotations from paleomagnetism in the Betics (mostly clockwise) and in the Rif (mostly counterclockwise) can be explained by westward rollback of an eastdipping subduction zone (Turner et al., 1999; see also Michard et al., 2002), but apparently other mechanisms can explain that as well (Hindle and Burkhard, 1999; Balanyá et al., 2007). Geochemistry of volcanic rocks in Spain and Morocco has also been proposed to support subduction (Duggen et al., 2004) in that they indicate a contamination of the mantle source with hydrous fluids/melts. However, geochemical evidence from volcanic rocks in the Gibraltar arc has also been interpreted as being due to a combination of both mechanisms, subduction and delamination (Duggen et al., 2005; Booth-Rea et al., 2007).

Focal mechanisms (Stich et al., 2003), as well as GPS measurements (e.g., Fadil et al., 2006) show that the Alboran Sea is currently opening toward the West or Southwest. Seismicity hypocenters themselves do not show a clear Benioff zone, but there are occasionally deep earthquakes at depths around $600 \mathrm{~km}$ (Buforn et al., 1991, 1997). The occurrence of such deep quakes is familiar from several subduction zones around the Earth, and also the focal mechanisms of these events that show East-West P- and T-axes are consistent with a subduction zone origin. Seismicity at intermediate depth is more enigmatic (e.g., Casado et al., 2001). Neither the distribution of hypocenters nor the focal mechanisms are reminiscent of a classical subduction zone that would be oriented in the same direction. P- and T-axes are more frequently in $\mathrm{N}-\mathrm{S}$ direction, more in line with the crustal stress field (see Stich et al., 2005; Fernández-Ibáñez et al., 2007) and the relative motion (e.g., Stich et al., 2006) of the surface. This depth variation apparently reflects the complex geodynamic situation that results from a subduction zone embedded into an active transpressional plate boundary.

It is also possible that the nature of the subducted lithosphere has changed with time. Surface tectonics suggests that the direction of extension has changed from North-South to East-West between 20 and $14 \mathrm{Ma}$ ago, accompanied by a thermal event. It may be argued that this corresponds to a change from a North-South (continental) subduction to an East-West oceanic subduction. In fact, our dispersion observations indicate a low-velocity crust in the topmost portion of the slab. That portion of the slab will be composed mostly of material younger than $14 \mathrm{Ma}$, if the subduction velocity is at least several $\mathrm{mm} / \mathrm{yr}$, and we will be unable to see a deeper portion where the low-velocity channel is perhaps missing.

Interestingly, Calvert et al. (2000a) have addressed the question as to whether the slab is continuous or not between 200 and $600 \mathrm{~km}$, but they showed in a 'smearing test' that tomography is unfortunately not yet capable of distinguishing a gap between two different slabs from a single continuous slab. The dispersion observations are of interest for this question, since they require a continuous slab over a certain depth range.

Besides the debate about the nature of the anomaly under the Alboran Sea, there is another one that concerns the question whether the subduction is still ongoing (e.g., Gutscher et al., 2002) or by now extinct (Sengör, 1993; Lonergan and White, 1997; Iribarren et al., 2007). No matter which of these two groups of authors is right, the zone is certainly tectonically active, as shown by the seismicity and the geodetic deformation. The open question is whether the zone is active only in the sense of a plate boundary, or whether the embedded subduction zone is still active. In any case, some of the intermediatedepth seismicity (nearly vertical line of seismicity) is indicative of a slab tear that is currently ongoing, and that is at least one sense in which the subduction may still be active. However, the precise relationship of this structure with the low- and high-velocity features still needs to be clarified. GPS velocity vectors and stress field inverted for the region (Stich et al., 2005, 2006, 2007) do not seem to require an active subduction of the oceanic portion.

There is an interesting similarity with the Calabrian arc in Southern Italy, for which shear-wave splitting results have been presented by Civello and Margheriti (2004) and more recently by Baccheschi et al. (2007). These authors find trench-parallel seismic fast orientations also for that region, and they show a spectacular rotation following the curvature of the rollback and of the mountain chain. The mirror symmetry of seismic anisotropy in the two arcs that are at opposite ends of the Western Mediterranean extension system is probably not fortuitous, but rather related to a similar phenomenon, and thus to the large-scale dynamics of oceanic domain opening in the Southwestern Mediterranean. The eastern slab rolled back toward the south-east, inducing the opening of both the Ligurian and Tyrrhenian Sea and letting its flow imprint in the upper mantle along its long retreating route (Barruol et al., 2004; Faccenna et al., 2004; Lucente et al., 2006). It is now well imaged through the upper mantle beneath present-day Calabrian arc and is probably lying within the transition zone (Piromallo and Morelli, 2003). The western slab fragment rolled back toward the south west, participating to the opening of the Algerian basin, generating the Alboran Sea and the Betic-Rif orocline.

\section{Conclusions}

We have presented two observational constraints that allow to critically test the geodynamic models that are most frequently discussed for the Alboran Sea region (Fig. 2). An oceanic model (retreating subduction) predicts that some P-waves should have a characteristic type of dispersion. Depending on the geometry of rays, this phenomenon may or may not be observed. We have searched for this phenomenon in waves at two stations, and have found that this occurs frequently (and exclusively) for waves propagating through the mantle under the Alboran Sea. This is strongly indicative of the presence of a subduction zone under the Alboran Sea. The second type of constraint was based on seismic anisotropy, which allows to critically test the continental model (convective removal) since that model predicts radial flow to occur towards the Alboran Sea. This phenomenon does not appear in the observations, given the current station distribution. On the other hand, a subduction-induced toroidal flow is quite consistent with the observations.

Both constraints thus strongly favour the oceanic subduction model. This resolves the most important question, namely that of the nature of the anomalous feature under the Alboran Sea. The second question, as to the shape of the anomaly is at this point less-well constrained. Ongoing and future experiments in the area will probably shed more light on the shape of the anomalies, and we will be able to learn how these processes occur in more detail. In particular, enhanced imaging techniques based on waveform imaging, use of later phases, and array-seismological techniques will be rather useful.

\section{Acknowledgements}

We thank Juan Carlos Balanyá Roure and an anonymous reviewer for reviews. 
We thank Andreas Wüstefeld for use of the SplitLab code (Wüstefeld et al. 2008; Wüstefeld and Bokelmann 2007) and help in the data processing. We wish to thank Marc-André Gutscher and Greg Houseman for interesting discussions. Some figures were created using GMT (Wessel and Smith, 1995). Data were used from the IAG-UGR and ROA-UCM-Geofon networks. We wish to acknowledge support by the CNRS/INSU through SEDIT grants, as well as Actions, and the French Ministry of the Exterieur (CNRS-CSIC project). We are also thankful for the financial support of the Spanish project CGL2008-01830-BTE, Junta de Andalucia RNM104 and the project Topo-Iberia CSD2006.

\section{References}

Abers, G.A., 2005. Seismic low-velocity layer at the top of subducting slabs: observations, predictions, and systematics. Phys. Earth Planet. Inter. 149, 7-29.

Abers, G.A., Sarker, G., 1996. Dispersion of regional body waves at $100-150 \mathrm{~km}$ depth beneath Alaska: in situ constraints on metamorphism of subducted crust. Geophys. Res. Lett. 23, 1171-1174.

Andrieux, J., Fontboté, J.M., Mattauer, M., 1971. Sur un modèle explicatif de l'arc de Gibraltar. Earth Planet. Sci. Lett. 12, 191-198.

Baccheschi, P., Margheriti, L., Steckler, M.S., 2007. Seismic anisotropy reveals focused mantle flow around the Calabrian slab (Southern Italy). Geophys. Res. Lett. 34, L05302. doi:10.1029/2006GL028899.

Balanyá, J.C., Crespo-Blanc, A., Diaz-Azpiroz, M., Expósito, I., Luján, M., 2007. Structural trend line pattern and strain partitioning around the Gibraltar Arc accretionary wedge: insights as to the mode of orogenic arc building. Tectonics 26. doi:10.1029/ 2005 TC001932.

Barruol, G., Mainprice, D., 1993. 3D seismic velocities calculated from LPOs and reflectivity of a lower crustal section - example of the Val Sesia (Ivrea Zone, Northern Italy). Geophys. J. Int. 115, 1169-1188.

Barruol, G., Deschamps, A., Coutant, O., 2004. Mapping upper mantle anisotropy beneath SE France by SKS splitting indicates a Neogene asthenospheric flow induced by the Apenninic slab rollback and deflected by the deep Alpine roots. Tectonophysics 394, 125-138. doi:10.1016/j.tecto.2004.08.002.

Barruol, G., Déverchères, J., Deschamps, A., Bokelmann, G.H.R., 2008. Upper mantle flow beneath the Hangay dome, central Mongolia. EPSL. doi:10.1016/j.epsl.2008.07.27.

Bijwaard, H., Spakman, W., Engdahl, E.R., 1998. Closing the gap between regional and global travel time tomography. J. Geophys. Res. 103, 30055-30078.

Bird, P., 1979. Continental delamination and the Colorado Plateau. J. Geophys. Res. 84, 7561-7571.

Blanco, M.J., Spakman, W., 1993. The P-wave velocity structure of the mantle below the Iberian Peninsula: evidence for subducted lithosphere below southern Spain. Tectonophysics 221, 13-34.

Bokelmann, G.H.R., Maufroy, E., 2007. Mantle structure under Gibraltar constrained by dispersion of body waves. Geophys. Res. Lett. 34, L22305. doi:10.1029/ 2007GL030964.

Booth-Rea, G., Ranero, C.R., Martínez-Martínez, J.M., Grevemeyer, I., 2007. Crustal types and Tertiary tectonic evolution of the Alborán sea, western Mediterranean. Geochem. Geophys. Geosyst. 8, Q10005. doi:10.1029/2007GC001639.

Buforn, E., Udias, A., Madariaga, R., 1991. Intermediate and deep earthquakes in Spain. Pageoph 136, 375-393.

Buforn, E., Coca, P., Udías, A., Lasa, C., 1997. Source mechanism of intermediate and deep earthquakes in southern Spain. J. Seismol. 1, 113-130.

Buontempo, L., Bokelmann, G.H.R., Barruol, G., Morales, J., 2008. Seismic anisotropy beneath southern Iberia from SKS splitting. Earth Planet. Sci. Lett. 273, 237-250. doi:10.1016/j.epsl.2008.07.027.

Calvert, A., Sandvol, E., Seber, D., Barazangi, M., Roecker, S., Mourabit, T., Vidal, F. Alguacil, G., Jabour, N., 2000a. Geodynamic evolution of the lithosphere and uppermantle beneath the Alboran Region of the western Mediterranean - constraints from travel-time tomography. J. Geophys. Res. 105, 10871-10898.

Calvert, A., Sandvol, E., Seber, D., Barazangi, M., Vidal, F., Alguacil, G., Jabour, N., 2000b. Propagation of regional seismic phases ( $\mathrm{Lg}$ and $\mathrm{Sn}$ ) and Pn velocity structure along the Africa-Iberia plate boundary zone: tectonic implications. Geophys. J. Int. 142, 384-408.

Casado, C., Sanz de Galdeano, C., Palacios, S., Romero, J., 2001. The structure of the Alboran Sea: an interpretation from seismological and geological data. Tectonophysics 338, 79-95.

Civello, S., Margheriti, L., 2004. Toroidal mantle flow around the Calabrian slab (Italy) from SKS splitting. Geophys. Res. Lett. 31, L10601. doi:10.1029/2004GL019607.

Coleman, R.G., Wang, X. (Eds.), 1995. Ultrahigh-Pressure Metamorphism. Cambridge University Press, New York. 528 pp.

Comas, M.C., Platt, J.P., Soto, J.I., Watts, A.B., 1999. The origin and tectonic history of the Alborán Basin: insights from Leg 161 results. In: Zahn, R., Comas, M.C., Klaus, A. (Eds.), Proc. ODP, Sci. Results. Ocean Drilling Program, College Station, TX. 555-579 pp.

Crespo-Blanc, A., Orozco, M., García-Dueñas, V., 1994. Extension versus compression during the Miocene tectonic evolution of the Betic chain. Late folding of normal fault systems. Tectonics 13, 78-88.

Dallmeyer, R.D., Martínez García, E., 1990. Pre-Mesozoic Geology of Iberia. SpringerVerlag, Berlin Heidelberg New York. 416 pp.
Diaz, J., Gallart, J., Hirn, A., Paulssen, H., 1998. Anisotropy beneath the Iberian Peninsula: the contribution of the ILIHA-NARS Broad-band Experiment. Pure Appl. Geophys. $151,395-405$

Diaz, J., Gallart, J., the Topolberia Seismic Working Group Team, 2009. SKS splitting in Southern Iberia and northern Morocco; first contributions of the IBERARRAY broadband seismic network. Geophys. Res. Abstr. 11 EGU2009-7376-1.

Docherty, C., Banda, E., 1995. Evidence for the eastward migration of the Alboran Sea based on regional subsidence analysis: a case for basin formation by delamination of the subcrustal lithosphere? Tectonics $14,804-818$.

Duggen, S., Hoernle, K., van den Bogaard, P., Harris, C., 2004. Magmatic evolution of the Alboran region: the role of subduction in forming the western Mediterranean and causing the Messinian Salinity Crisis. Earth Planet. Sci. Lett. 218, 91-108.

Duggen, S., Hoernle, K., Van den Bogaard, P., Garbe-Schonberg, D., 2005. Post-collisional transition from subduction- to intraplate-type magmatism in the westernmost Mediterranean: evidence for continental-edge delamination of subcontinental lithosphere. J. Petrol. 46, 1155-1201.

Faccenna, C., Piromallo, C., Crespo-Blanc, A., Jolivet, L., Rossetti, F., 2004. Lateral slab deformation and the origin of the western Mediterranean arcs. Tectonics 23, TC1012. doi:10.1029/2002TC001488.

Faccenna, C., Civetta, L., D'Antonio, M., Funiciello, F., Margheriti, L., Piromallo, C., 2005 Constraints on mantle circulation around the deforming Calabrian slab. Geophys. J. Int. $145,809-820$

Fadil, A., Vernant, P., McClusky, S., Reilinger, R., Gomez, F., Ben Sari, D., Mourabit, T., Feigl, K.L., Barazangi, M., 2006. Active tectonics of the western Mediterranean: GPS evidence for roll back of a delaminated subcontinental lithospheric slab beneath the Rif Mountains, Morocco. Geology 34, 529-532.

Fernández-Ibáñez, F., Soto, J.I., Zoback, M.D., Morales, J., 2007. Present-day stress field in the Gibraltar Arc (western Mediterranean). J. Geophys. Res. 112, B08404. doi:10.1029/2006JB004683.

Fontaine, F.R., Barruol, G., Tommasi, A., Bokelmann, G., Reymond, D., 2007. Upper mantle flow beneath Polynesia from shear-wave splitting. Geophys. J. Int. 170 1262-1288. doi:10.1111/j.1365-246X.2007.03475.x.

García-Dueñas, V., Balanyá, J.C., Martínez-Martínez, J.M., 1992. Miocene extensional detachments in the outcropping basement of the Northern Alboran Basin and their tectonic implications. Geo-Mar. Lett. 12, 88-95.

Godfrey, N.J., Christensen, N.I., Okaya, D.A., 2000. Anisotropy of schists: contribution of crustal anisotropy to active source seismic experiments and shear wave splitting observations. J. Geophys. Res. 105, 27991-28007.

Gubbins, D., Snieder, R., 1991. Dispersion of P waves in subducted lithosphere: evidence for an eclogite layer. J. Geophys. Res. 96, 6321-6333.

Gurria, E., Mezcua, J., Blanco, M.J., 1997. Crustal and upper mantle velocity structure of Southern Iberia, the sea of Alboran, and the Gibraltar arc determined by local earthquake tomography. Ann. Geofis. 40 (1), 123-132.

Gutscher, M.A., Malod, J., Rehault, J.P., Contrucci, I., Klingelhoefer, F., Mendes, V.L., Spakman, W., 2002. Evidence for active subduction beneath Gibraltar. Geology 30, 1071-1074.

Gutscher, M.A., Malod, J., Rehault, J.P., Contrucci, I., Klingelhoefer, F., Mendes, V.L Spakman, W., 2003. Reply to comment "Evidence for active subduction beneath Gibraltar". Geology 30, 1071-1074.

Hindle, D., Burkhard, M., 1999. Strain, displacement and rotation associated with the formation of curvature in fold belts; the example of the Jura Arc. J. Struct. Geol. 21 1089-1101.

Houseman, G.A., Molnar, P., 1997. Gravitational (Rayleigh-Taylor) instability of a laye with nonlinear viscosity and convective thinning of continental lithosphere. Geophys. J. Int. 128, 125-150.

Houseman, G.A., McKenzie, D.P., Molnar, P., 1981. Convective instability of a thickened boundary layer and its relevance for the thermal evolution of continental convergent belts. J. Geophys. Res. 86, 6115-6132.

Iribarren, L., Verges, J., Camurri, F., Fullea, J., Fernandez, M., 2007. The structure of the Atlantic-Mediterranean transition zone from the Alboran Sea to the Horseshoe Abyssal Plain (Iberia-Africa plate boundary). Mar. Geol. 243 (1-4), 97-119 ISSN 0025-3227.

Jabaloy, A., Galindo-Zaldívar, J., González-Lodeiro, F., 1992. The Mecina Extensional System: its relation with the post-Aquitanian piggy-back basins and the paleostresses evolution (Betic Cordilleras, Spain). Geo-Mar. Lett. 12, 96-103.

Jolivet, L., Augier, R., Faccenna, C., Negro, F., Rimmele, G., Agard, P., Robin, C., Rossetti, F., Crespo-Blanc, A., 2008. Subduction, convergence, and the mode of backarc extension in the Mediterranean region. Bull. Soc. Géol. Fr. 179 (6), 525-550.

Jung, H., Karato, S., 2001. Water-induced fabric transitions in olivine. Science 293, 1460-1463. doi:10.1126/science.1062235.

Karato, S., Wu, P., 1993. Rheology of the upper mantle - a synthesis. Science 260 771-778.

Lonergan, L., White, N., 1997. Origin of the Betic-Rif mountain belt. Tectonics 16 504-522.

Long, M.D., Silver, P.G., 2008. The subduction zone flow field from seismic anisotropy: a global view. Science 319, 315-318.

Lucente, F.P., Margheriti, L., Piromallo, C., Barruol, G., 2006. Seismic anisotropy reveals the long route of the slab through the western-central Mediterranean mantle. Earth Planet. Sci. Lett. 241, 517-529. doi:10.1016/j.epsl.2005.10.041.

Mainprice, D., Silver, P.G., 1993. Interpretation of SKS-waves using samples from the subcontinental lithosphere. Phys. Earth Planet. Inter. 78, 257-280. doi:10.1016 0031-9201(93)90160-B.

Mainprice, D., Barruol, G., Ben Ismail, W., 2000. The seismic anisotropy of the Earth's mantle: from single crystal to polycrystal. In: Karato, S.I. (Ed.), Earth's Deep Interior: Mineral Physics and Tomography from the Atomic to the Global Scale. : Geodyn. Ser., 117. AGU, Washington, D.C, pp. 237-264. 
Mainprice, D., Tommasi, A., Couvy, H., Cordier, P., Frost, D.J., 2005. Pressure sensitivity of olivine slip systems: implications for the interpretation of seismic anisotropy of the Earth's upper mantle. Nature 433, 731-733.

Martin, S., 2005. Subduction zone wave guides: deciphering slab structure using intraslab seismicity at the Chile-Peru subduction zone, PhD thesis, Universität Potsdam, $122 \mathrm{pp}$

Martínez-Martínez, J.M., Azañón, J.M., 1997. Mode of extensional tectonics in the southeastern Betics (SE Spain): implications for the tectonic evolution of the periAlboran orogenic system. Tectonics 16 (2), 205-225.

Martínez-Martínez, J.M., Booth-Rea, G., Azañón, J.M., Torcal, F., 2006. Active transfer fault zone linking a segmented extensional system (Betics, southern Spain): insight into heterogeneous extension driven by edge delamination. Tectonophysics 422 , 159-173.

Mezcua, J., Rueda, J., 1997. Seismological evidence for a delamination process in the lithosphere under the Alboran Sea. Geophys. J. Int. 129, F1-F8.

Michard, A., Chalouan, A., Feinberg, H., Goffé, B., Montigny, R., 2002. How does the Alpine belt end between Spain and Morocco? Bull. Soc. Geol. Fr. 173 (1), 3-15.

Morales, J., Serrano, I., Jabaloy, A., Galindo-Zaldívar, J., Zhao, D., Torcal, F., Vidal, F. González Lodeiro, F., 1999. Active continental subduction beneath the Betic Cordillera and the Alborán Sea. Geology 27, 735-738.

Nicolas, A., Christensen, N.I., 1987. Formation of anisotropy in upper mantle peridotites - a review. In: Fuchs, K., Froideveaux, C. (Eds.), Composition Structure and Dynamics of the Lithosphere Asthenosphere System. AGU, Washington D.C., pp. 111-123.

Piromallo, C., Morelli, A., 1997. Imaging the Mediterranean upper mantle by P-wave travel time tomography. Ann. Geofis. 40, 963-979.

Piromallo, C., Morelli, A., 2003. P wave tomography of the mantle under the AlpineMediterranean area. J. Geophys. Res. 108 (B2). doi:10.1029/2002JB001757.

Platt, J., Houseman, G., 2003. Comment to "Evidence for active subduction beneath Gibraltar" by Gutscher, M.A., Malod, J., Rehault, J.P., Contrucci, I., Klingelhoefer, F., Mendes, V.L., Spakman, W., 2002. Geology 30, 1071-1074.

Platt, J.P., Vissers, R.L.M., 1989. Extensional collapse of thickened continental lithosphere: a working hypothesis for the Alboran Sea and Gibraltar Arc. Geology $17,540-543$.

Platt, J.P., Soto, J.I., Whitehouse, M.J., Hurford, A.J., Kelley, S.P., 1998. Thermal evolution, rate of exhumation, and tectonic significance of metamorphic rocks from the floor of the Alboran extensional basin, western Mediterranean. Tectonics 17, 671-689.

Plomerova, J., Payo, G., Babuska, V., 1993. Teleseismic P-residual study in the Iberian Peninsula. Tectonophysics 221, 1-12.

Royden, L.H., 1993. Evolution of retreating subduction boundaries formed during continental collision. Tectonics 12, 629-638.

Russo, R., Silver, P., 1994. Trench-parallel flow beneath the Nazca Plate from seismic anisotropy. Science 263, 1105-1111.

Sanz de Galdeano, C., 1990. Geological evolution of the Betic Cordillera in the western Mediterranean, Miocene to Present. Tectonophysics 172, 107-119.

Savage, M.K., 1999. Seismic anisotropy and mantle deformation: what have we learned from shear wave splitting? Rev. Geophys. 37, 69-106.

Schmid, C., Van der Lee, S., Giardini, D., 2004. Delay times and shear wave splitting in the Mediterranean region. Geophys. J. Int. 159, 275-290.

Seber, D., Barazangi, M., Ibenbrahim, A., Demnati, A., 1996a. Geophysical evidence for lithospheric delamination beneath the Alboran Sea and Rif-Betic mountains. Nature 379, 785-790.

Seber, D., Barazangi, M., Ibenbrahim, A., Demnati, A., 1996b. Geophysical evidence for lithospheric delamination beneath the Alboran Sea and Rif-Betics mountains. Nature 379, 785-790.

Sengör, A.M.C., 1993. Some current problems on the tectonic evolution of the Mediterranean during the Cainozoic. In: Boschi, E., Mantovani, E., Morelli, A (Eds.), Recent Evolution and Seismicity of the Mediterranean Region. Kluwer Acad, Norwell, Mass, pp. 1-51.

Serrano, I., Hearn, T.M., Morales, J., Torcal, F., 2005. Seismic anisotropy and velocity structure beneath the southern half of the Iberian peninsula. Phys. Earth Planet. Inter. 150 (4), 317-330.

Sieminski, A., Liu, Q., Trampert, J., Tromp, J., 2007. Finite-frequency sensitivity of body waves to anisotropy based upon adjoint methods. Geophys. J. Int. 171, 368-389. doi:10.1111/j.1363-246X.2007.03528.X.
Silver, P.G., 1996. Seismic anisotropy beneath the continents: probing the depths of geology. Annu. Rev. Earth Planet. Sci. 24, 385-432.

Silver, P.G., Savage, M., 1994. The interpretation of shear-wave splitting parameters in the presence of two anisotropic layers. Geophys. J. Int. 119, 949-963.

Silver, P.G., Mainprice, D., Ben Ismail, W., Tommasi, A., Barruol, G., 1999. Mantle structural geology from seismic anisotropy, in: mantle petrology: field observations and high pressure experimentations: a tribute to Francis R. (Joe) Boyd. Geochem. Soc. Spec. Publ. 6, 79-103.

Spakman, W., van der Lee, S., van der Hilst, R., 1993. Travel-time tomography of the European-Mediterranean mantle down to $1400 \mathrm{~km}$. Phys. Planet. Inter. 79, 3-74.

Stich, D., Ammon, C.J., Morales, J., 2003. Moment tensor solutions for small and moderate earthquakes in the Ibero-Maghreb region. J. Geophys. Res. 108, 2148. doi:10.1029/2002JB002057.

Stich, D., Mancilla, F., Morales, J., 2005. Crust-mantle coupling in the Gulf of Cadiz (SWIberia). Geophys. Res. Lett. 2, L13306. doi:10.1029/2005GL023098.

Stich, D., Serpelloni, E., Mancilla, F., Morales, J., 2006. Kinematics of the Iberia-Maghreb plate contact from seismic moment tensors and GPS observations. Tectonophysics 426, 295-317.

Stich, D., Mancilla, F., Pondrelli, S., Morales, J., 2007. Source analysis of the February 12th 2007, Mw 6.0 Horseshoe earthquake: implications for the 1755 Lisbon earthquake. Geophys. Res. Lett. 34, L12308. doi:10.1029/ 2007GL030012.

Thiebot, E., Gutscher, M.-A., 2006. The Gibraltar Arc seismogenic zone (part 1): constraints on a shallow east dipping fault plane source for the 1755 Lisbon earthquake provided by seismic data, gravity and thermal modeling. Tectonophysics 426, 135-152.

Torres-Roldan, R.L., Poli, G., Peccerillo, A., 1986. An early Miocene arc-tholeitic magmatic dike event from the Alboran Sea: evidence for precollision subduction and back-arc crustal extension in the westernmost Mediterranean. Geol. Rundsch. $75,219-234$.

Turner, S.P., Platt, J.P., George, R.M.M., Kelley, S.P., Pearson, D.G., Nowell, G.M., 1999. Magmatism associated with orogenic collapse of the Betic-Alboran Domain. SE Spain. J. Petrol. 40, 1011-1036.

Vauchez, A., Garrido, C., 2001. Seismic properties of an asthenospherized lithospheric mantle: constraints from lattice preferred orientations in peridotite from the Ronda Massif. Earth Planet. Sci. Lett. 192, 245-259.

Villasenor, A Yang Y, Ritzwoller, M.H. Gallart, J. 2007. Ambient noise surface wave tomography of the Iberian Peninsula: implications for shallow seismic structure. Geophys. Res. Lett. 34, L11304. doi:10.1029/2007GL030164.

Walker, K.T., Bokelmann, G.H.R., Klemperer, S.L., 2001. Shear-wave splitting to test mantle deformation models around Hawaii. Geophys. Res. Lett. 28 (22), 3219-3322.

Walker, K., Bokelmann, G.H.R., Klemperer, S., Bock, G., 2004a. Mantle anisotropy beneath the Snake River Plain suggests a mantle upwelling beneath eastern Nevada, USA. Earth Planet. Sci. Lett. 222, 529-542.

Walker, K.T., Nyblade, A.A., Bokelmann, G.H.R., Klemperer, S.L., Owens, T.J., 2004b. On the relationship between extension and anisotropy: constraints from shear wave splitting across the East African Plateau. J. Geophys. Res. 109, B0802. doi:10.1029/ 2003JB002866.

Walker, K.T., Bokelmann, G.H.R., Klemperer, S.L., Bock, G., 2005. Shear-wave splitting around the Eifel hotspot: evidence for a mantle upwelling. Geophys. J. Int. 163, 962-980

Wortel, M.J.R., Spakman, W., 2000. Subduction and slab detachment in the Mediterranean-Carpathian region. Science 290, 1910-1917.

Wüstefeld, A., Bokelmann, G.H.R., 2007. Null detection in shear-wave splitting measurements. Bull. Seismol. Soc. Am. 97 (4), 1204-1211.

Wüstefeld, A., Bokelmann, G.H.R., Zaroli, C., Barruol, G., 2008. SplitLab: a shear-wave splitting environment in Matlab. Comput Geosci. 34, 515-528 doi:10.1016/j.cageo 2007.08.002.

Yamato, P., Burov, E., Agard, D., Le Pourheit, L., Jolivet, L., 2008. HP-UHP exhumation during slow continental subduction: self-consistent thermodynamically and thermomechanically coupled models with application to the Western Alps. Earth Planet. Sci. Lett. 271, 63-74.

Zeck, H.P., 1996. Betic-Rif orogeny:subduction of Mesozoic Tethys lithosphere under eastward drifting Iberia, slab detachment shortly before $22 \mathrm{Ma}$, and subsequent uplift and extensional tectonics. Tectonophysics 254,1-16. 